EESTI NSV TEADUSTE AKADEEMIA TOIMETISED. XVI KÖIDE

KEEMIA * GEOLOOGIA. 1967, NR. 1

ИЗВЕСТИЯ АКАДЕМИИ НАУК ЭСТОНСКОИ ССР. ТОМ ХVI

Химия * ГЕОлогия. 1967, 추 1

А. ЭРМ, К. ЛЭЭТС

\title{
ИССЛЕДОВАНИЕ РЕАКЦИИ ТЕЛОМЕРИЗАЦИИ ИЗОПРЕНА С УКСУСНОИ КИСЛОТОЙ
}

Впервые реакция изопрена с уксусной кислотой описана Т. Вагнер-Яурегом [1] в 1932 г., а позднее - Т. Леннарцом [2]. Ими показано, что под каталитическим воздействием серной кислоты в среде уксусной кислоты изопрен образует сложную смесь геми-, моно- и сесквитерпеновых ацетатов и углеводородов. Гидролиз продукта реакции позволил выделить из него некоторые спирты, из которых удалось идентифицировать $\gamma, \gamma$-диметнлаллиловый спирт (пренол), линалоол, гераниол, $\alpha$-терпинеол и фарнезол.

Далее Э. Дженнер [], изучивший реакцию дивиннла с карбоновыми кислотами в присутствии минеральных кнслот, приписал указанной реакции характер реакции нонно-каталитической теломеризации.

Кроме того, в патентной литературе $\left[{ }^{4}, 5\right]$ указывается на возможность получения пенных производных гераниола, представляющих практический интерес, при помощи реакции изопрена с карбоновыми кислотами.

Нас интересовал вопрос о возможности применения реакции теломеризации изопрена с уксусной кислотой для синтеза ценных терпеновых спиртов линалоола и гераниола. Также представляло научный интерес установление закономерностей данной реакции и сравнение их с закономерностями, установленными ранее одним из авторов для реакцни теломеризации изопрена с его гидрохлоридами $\left[{ }^{6}, 7\right]$.

В настоящей работе изучалось влияние различных условий, а также природы катализаторов на скорость реакции, выход и состав продуктов реакции теломеризации изопрена с уксусной кислотой. При этом для анализа и определения изомерного состава полученных продуктов использовались методы газовой хроматографии терпеновых оксипроизводных, изученные нами ранее [8,9].

Первые опыты, проведенные в условиях, близких к описанным в $\left[{ }^{2}\right]$, показали, что при данной реакции наряду с ацетатами спиртов вследствие дегидратации образуется значительное количество терпеновых углеводородов. Последние осложняют газохроматографический анализ фракций, полученных после разгонки, так как на хроматограмме пики ацетатов $\mathrm{C}_{10}$ перекрываются пиками углеводородов $\mathrm{C}_{15}$, перегонявшихся вместе в результате образования азеотропов. 
Не было получено удовлетворительных результатов газохроматографического анализа и после гидролиза ацетатов в спирты. В связи с этим для разделения углеводородов и спиртов были испытаны методы фталирования $\left[{ }^{2}\right]$ и борирования $\left[{ }^{10}\right]$. Нами установлено, что использование этих методов не обеспечивает получения хроматограмм для количественного сравнения состава продуктов реакции отдельных опытов из-за сложности проведения этих реакций в строго одинаковых условиях.

Вполне удовлетворительно удалось отделить терпеновые спирты от углеводородов с помощью многоступенчатой распределительной экстракции по схеме, описанной в экспериментальной части (рис. 1). Как видно из хроматограмм (рис. 2 и 3), при такой экстракции гидролизата фракции $\mathrm{C}_{10} 90 \%$-ным метанолом и петролейным эфиром можно с хорошим выходом отделить терпеновые углеводороды от спиртов $\mathrm{C}_{10}$. При этом соотношения главных пиков на хроматограммах до и после экстракции остаются неизменными, а спиртов во фракции углеводородов остается незначительное количество. Фракция спиртов практически не содержит углеводородов. Это позволило применить данную методику для количественного анализа получаемых продуктов теломеризации.

В целях изучения индивидуального состава фракции спиртов $\mathrm{C}_{10}$ было предпринято разделение этой фракции на препаративном газовом хроматографе, описанном ранее [9]. В результате проведенного разделения удалось выделить очищенные фракции основных компонентов смеси спиртов $\mathrm{C}_{10}$ (пики $8,9,11$ и 18 на хроматограмме рис. 2). Для полученных фракший были сняты инфракрасные спектры (рис. 4). По спектрам удалось идентифицировать $a$-терпинеол (пик 11) и гераниол (пик 18), однако спектров, соответствующих остальным спиртам (пики 8 и 9), не удалось найти в литературе. Характеристика выделенных спиртов приведена в табл. 1.

Таблица 1

Характеристика препаративно выделенных продуктов реакции изопрена с уксусной кислотой

\begin{tabular}{|c|c|c|c|c|c|c|c|c|}
\hline 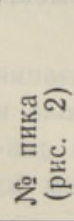 & Вещество & 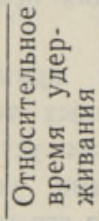 & 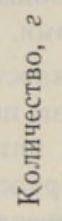 & $n_{D}{ }^{20}$ & $\begin{array}{c}T_{\text {киा }} \\
{ }^{\circ} \mathrm{C}(5 \text { м. })\end{array}$ & 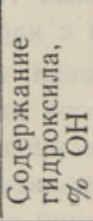 & $\begin{array}{l}\text { Бромное } \\
\text { число, } \\
\frac{2 \mathrm{Br}_{2}}{1002} \\
\text { вещества }\end{array}$ & 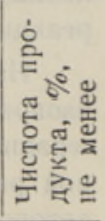 \\
\hline 8 & Спирт & 0,43 & 0,8 & 1,4 & & 11 & 142 & 95 \\
\hline 9 & Спирт & 0,47 & 0,2 & 1,4716 & $78-80$ & 11 & 162 & 85 \\
\hline 11 & Спирт ( $\alpha$-терпинеол) & 0,51 & 1,6 & 1,4826 & $80-82$ & 11 & 76 & 98 \\
\hline 18 & Спирт (гераниол) & 1,00 & 1,8 & 1,4765 & $92-94$ & 11 & 153 & 95 \\
\hline
\end{tabular}

Целью настоящей работы было исследование возможности прямого синтеза ценных терпеновых спиртов линалоола и гераниола на базе изопрена. Поэтому нас интересовал вопрос о влиянии условий реакции на индивидуальный состав фракции спиртов $\mathrm{C}_{10}$. Были проведены опыты для выяснения оптимальных условий реакции и наилучшего катализатора. Результаты этих опытов приведены в табл. 2 и 3. В табл. 2 характеризуется выход отдельных фракций в зависимости от условий реакции и катализаторов, в табл, 3 приводятся данные об 


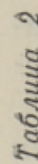

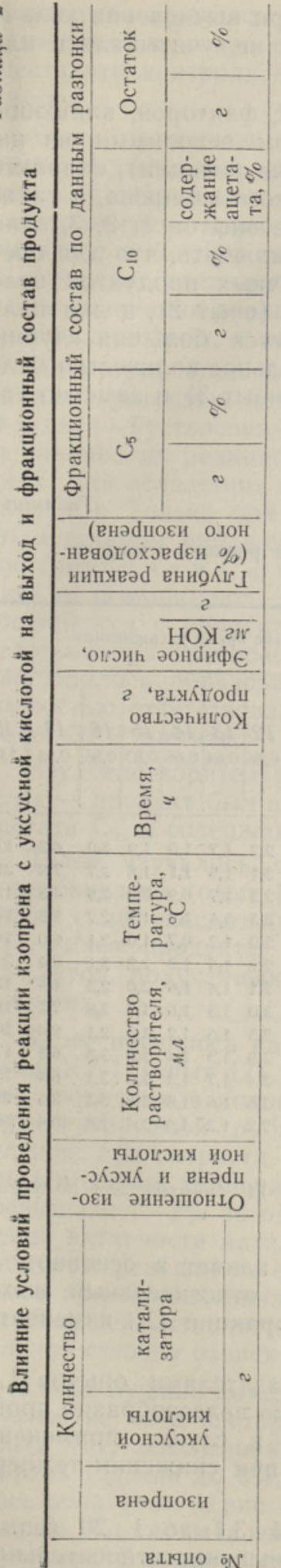

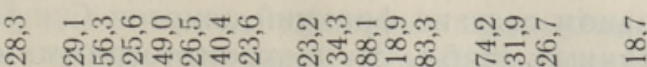

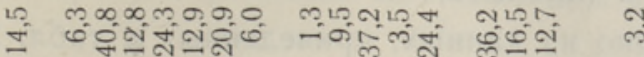

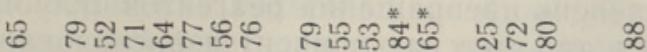

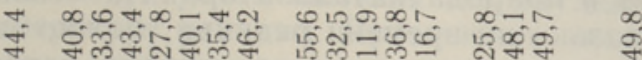

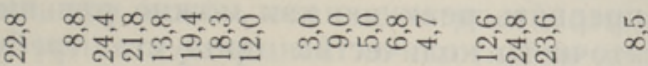

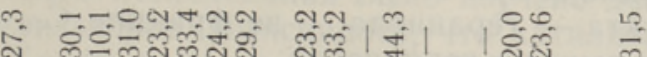

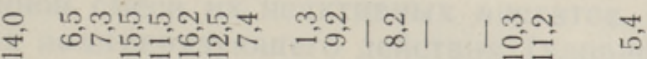

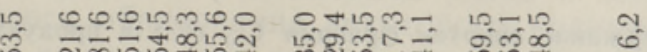

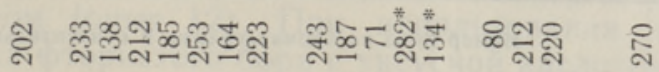

m.

L10

ヘ

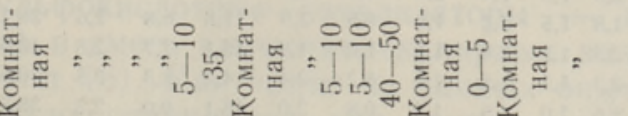

유유ํำ 융

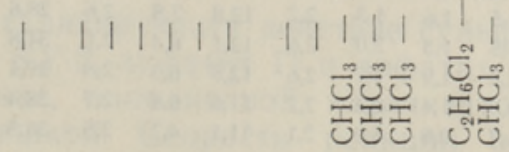

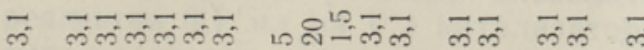

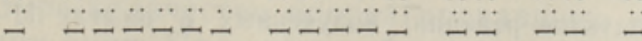

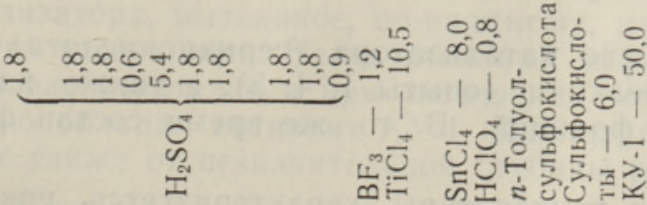

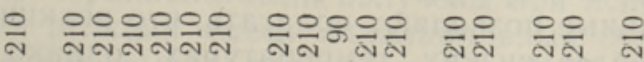

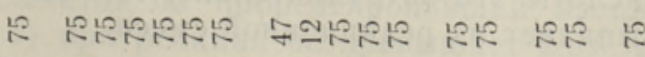

- amtron $\infty 00= \pm$ m$$
\frac{1}{2}
$$

है

음

กิ

总

율

를

$\infty$ 
индивидуальном составе фракций спиртов $\mathrm{C}_{10}$. При вычислении количественных данных (табл. 3) по хроматограммам не учитывалась площадь пика 2 (пренола).

Как видно из данных, приведенных в табл. 2, факторов, влияющих на состав и выход продуктов, много; при этом основными из них являются степень превращения реагентов (глубина реакции), охарактеризованная в таблице как процент израсходованного изопрена, а также температура и природа катализатора. На основе опытов 1, 2, 3, отличающихся только по времени реакции, можно заключить, что для обеспечения лучшего относительного выхода первичных продуктов целесообразно прервать реакцию как можно раньше (опыт 2), а для получения достаточного количества продукта требуется большая глубина реакции. Однако при этом уменышается относительное количество целевого продукта - гераниола - во фракции $\mathrm{C}_{10}$ (опыт 3 ) и заметно увеличивается выход $\alpha$-терпинеола.

Таблица 3

Содержание спиртов фракции $\mathrm{C}_{10}(\%)$ в продукте реакции изопрена с уксусной кислотой

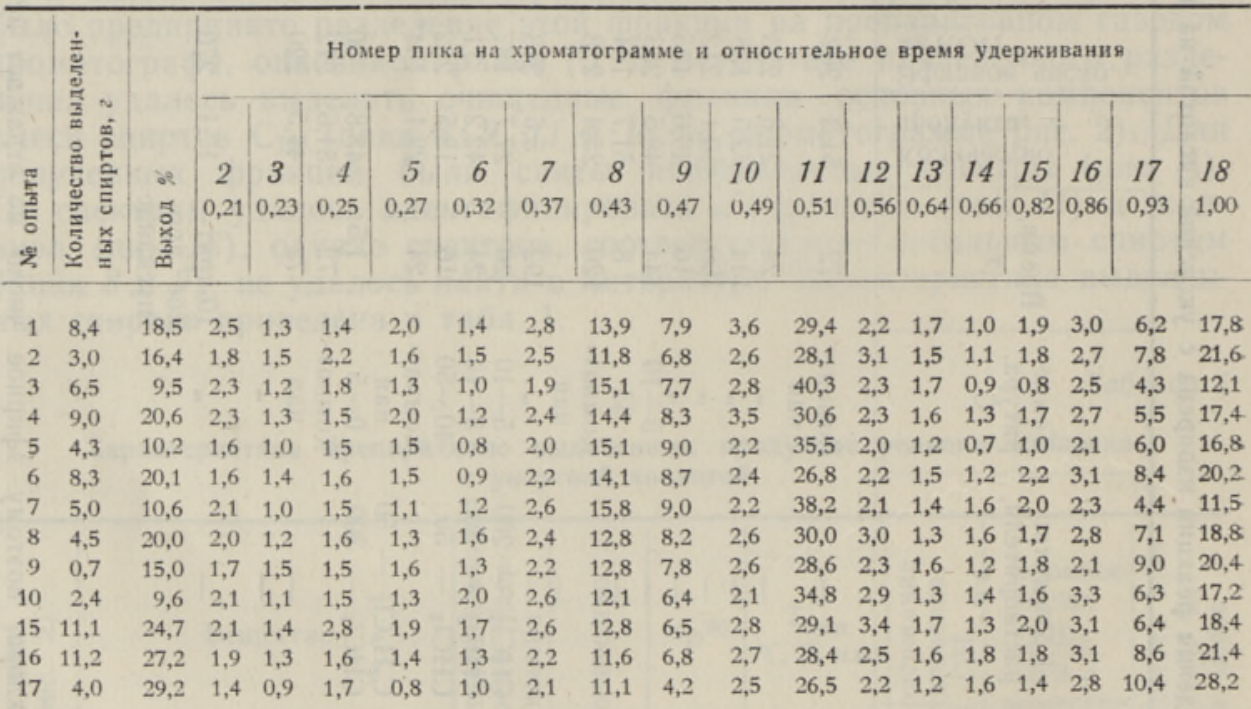

* I/з продуктов реакции, полученных в опытах $11-14$, спиртов для получения сравнительных хроматограмм выделить не удалось.

Количество катализатора (серная кислота) влияет в основном на скорость реакции (опыты $1,4,5)$, а также на относительный выход отдельных фракций. $\mathrm{B}$ то же время состав фракции $\mathrm{C}_{10}$ изменяется мало.

Влияние температуры характеризуется показателями опытов 1,6 и 7. Эти данные позволяют полагать, что реакцию целесообразно проводить при более низких температурах, однако в случае применения уксусной кислоты это затруднительно, так как при снижении температуры она выпадает из реакционной смеси.

Соотношение реагентов варьировалось от $1: 3,1$ до $1: 20$ (опыты $1,8,9)$. Қак видно из полученных данных, уменьшение относительного 
количества изопрена улучшает выход первичных продуктов реакции, но замедляет ее скорость; кроме того, при этом становится трудно осуществлять контроль за глубиной реакции по плотности реакционной смеси.

Были проведены опыты с применением растворителей. Целесообразными оказались растворители, содержащие хлор (хлороформ опыт 10, дихлорэтан и др.), которые позволяют уменьшить относительное количество применяемой уксусной кислоты без ухудшения состава продукта и снизить температуру реакции. Применение этилового эфира в качестве растворителя затрудняет вымывание уксусной кислоты после окончания реакции; при использовании петролейного эфира образуются две фазы, и контроль за реакцией по плотности неосуществим.

На втором этапе данного исследования было изучено действие различных протонных катализаторов. Выяснилось, что катализаторы типа Фриделя-Густавсона-Крафтса не дают желаемых результатов из-за выпадания из реакционной смеси их неактивных ацетатов (хлористый цинк) или вследствие их полимеризующего действия (хлорное олово опыт 13). Только при нагревании реакционной смеси с четыреххлористым титаном наблюдалось образование некоторого количества ацетатов спиртов $\mathrm{C}_{5}$ и $\mathrm{C}_{10}$, но из-за малого содержания их не удалось выделить из реакционной смеси. Было замечено, что некоторая часть хлора соединяется с продуктом (опыт 12). При использовании в качестве катализатора комплекса фтористого бора с уксусной кислотой (опыт 11) наблюдалось образование высокомолекулярного продукта, при этом полностью отсутствовала фракция ацетатов $\mathrm{C}_{5}$; фракция $\mathrm{C}_{10}$ содержала менее $50 \%$ ацетата.

Неудовлетворительные результаты дало и применение хлорной кислоты - продукт был высокомолекулярный; кроме того, он не содержал ацетата $\mathrm{C}_{5}$, а содержание ацетатов $\mathrm{C}_{10}$ было низкое (опыт 14).

Далее изучались сульфокислотные катализаторы - паратолуолсульфокислота (опыт 15) и смесь высокомолекулярных алкилароматических сульфокислот (опыт 16). Как видно из данных опытов 15 и 16, полученные продукты мало отличаются как друг от друга, так и от продуктов, полученных под влиянием серной кислоты в аналогичных условиях.

Далее изучалось катализирующее действие сульфокислотных катионитов КУ-1 (опыт 17), КУ-2, вофатит П и вофатит Ф. При этом реакшию проводили в колонке, наполненной катализатором и снабженной термостатируемой рубашкой. Скорость реакции оказалась незначительной: при скорости реагентов 0,1 мл на 1 г катализатора в минуту при комнатной температуре количество прореагировавшего изопрена не превышало $1-2 \%$ за один цикл. При этом наблюдалось быстрое уменьшение активности катализатора, вызванное, по-видимому, накоплением продуктов реакции на его поверхности. Незначительный эффект наблюдался при прибавлении растворителей и при повышении температуры. Наибольшей активностью обладал катионит КУ-1. Данные опыта 17 в сильной степени зависят также от незначительной глубины реакции.

Самые лучшие выходы гераниола были получены при использовании в качестве катализатора реакции смеси алкиларильных сульфокислот (опыт 16), обеспечивающих выход гераниола до $21 \%$ от фракции спиртов $\mathrm{C}_{10}$ или до $6 \%$, считая на прореагировавший изопрен. Выход линалоола (пик 4 , рис. 3) при реакции не превышает $2,5 \%$ от фракции спиртов $\mathrm{C}_{10}$, и выделение чистого линалоола представляет большие трудности. В связи с этим идентификация линалоола по методу Г. Лен- 
нарца [2] остается под сомнением, так как возможно, что фталирование первичных спиртов не обеспечивает полного удаления гераниола из гидролизата фракции $\mathrm{C}_{10}$ (по полученным нами данным) и остатки гераниола при дальнейшей обработке приняты за продукт изомеризации линалоола.

В итоге можно заключить, что реакция изопрена с уксусной кислотой является реакцией ионно-каталитической теломеризации. Однако состав фракции $\mathrm{C}_{10}$ более сложен, чем при реакции ионно-каталитической теломеризации изопрена с его гидрохлоридами [ $\left.{ }^{7}\right]$, что объясняется гидратирующим и дегидратирующим действием применяемых кислотных катализаторов.

\section{Экспериментальная часгь}

1. Исходные вещества. Химически чистая ледяная уксусная кислота без предварительной обработки.

Изопрен - технический, содержавший до 5\% полимеров и нкгибиторов (по данным перегонки), обрабатывался металлическим натрием в течение 6 ч при температуре кипения и перегонялся над свежей порцией металлического натрия. Был получен продукт с температурой кипения $T_{\text {кип }}=34 \div 35^{\circ} \mathrm{C} ; \quad d_{4}{ }^{20}=0,6780$ и $n_{D}{ }^{20}=1,4228$. Чистота изопрена, определенная методом газовой хроматографии, составляла $99,3 \%$, в нем присутствовали примеси метилбутенов.

Қатализаторы: химически чистые безводные хлорнды олова, цинка и титана в растворе дихлорэтана или хлороформа, серная кислота удельного веса 1,84. 30\%-ный раствор хлорной кислоты обезвоживался при реакции с расчетным количеством уксусного ангидрида; полученный раствор $\mathrm{HClO}_{4}$ в уксусной кислоте применялся для проведения реакции. Таким же образом обезвоживалась смесь алкиларильных сульфокислот, синтезированная в нашем институте, $n$-Толуолсульфокислота перекристаллизовывалась из горячей $\mathrm{HCl}$ и длительное время высушивалась над $\mathrm{KOH}$.

Ионообменные смолы переводились в кислотную форму по методике, описанной f. [1']. После этого воздушно-сухой ионит обезвоживался кипячением в суспензии с октаном на установке с обратным холодильником и ловушкой для воды. Большинство октана выпаривалось в небольшом вакууме, а остатки его перегонялись вместе с прибавленной уксусной кислотой. Суспензия катионита в уксусной кислоте переносилась в колонку для проведения реакции.

Қомплекс фтористого бора был изготовлен по реакции, огисанной в [12]. Выделяющийся $\mathrm{BF}_{3}$ абсорбировался в склянке с $\mathrm{CH}_{3} \mathrm{COOH}$, охлаждающейся снаружн. По увеличению веса склянки вычисляли концентрацию полученного комплекса. Применявшиеся для проведения реакцин растворители были заранее обезвожены соответствуюшими способами, описанными в литературе [13].

2. Реакция теломеризации. В круглодонную колбу с мешалкой, термометром, обратным холодильником и прибором для определения плотности смеси помещалось 210 г уксусной кислоты, 0,2 г гидрохинона и определеннсе количество катализатора. При энергичнсм перемешивании и охлаждєнии водой снаружи прибавлялось 75 ᄅ (или иное рассчитанное количество) изопрена. После определения начальной плотности реакционной смеси $\left(d_{15}{ }^{15}=0,918\right)$ последняя выдерживалась при комнатной температуре до необходимого прироста плотности $\left(d_{15}{ }^{15}=0,980 \div 0,985\right)$, чго соответствует глубине реакции около $50 \%$ по количеству прореагировавшего нзопрена. В опытах, проведенных при температуре $5-10^{\circ}$, применялось охлаждение ледяной водой с последующим выдерживанием реакционной смесп в холодильном шкафу; в случае применения повышенной температуры реакционную смесь после прибазления изопрена нагревали на водяной бане. Продукт реакции для извлечения уксусной кислоты и 
катализатора обрабатывался водой $(1 \Omega)$. Для уменьшения потерь продукта водный слой частично нейтрализовался прибавленисм поташа и дополнительно экстрагировался петролейным эфиром $\left(T_{\text {кип }}=40 \div 60^{\circ}\right)$. Масляный слой промывался водой $\mathrm{c}$ $5 \%$-ным бикарбонатом натрия и высушивался над безводным поташом. После отгонки изопрена и петролейного эфира определяли вес продукта и содержание в нем ацетильных групп.

Для проведения реакции с гетерогенными катализаторами (ионообменные смолы) катализатор в суспензии с уксусной кислотой переноснлся в колонку с термостатируемой рубашкой. После достижения колонкой требуемой температуры составленную заранее смесь изопрена и уксусной кислоты пропускали через нее несколько раз до получения необходимой глубины реакции. По окончании реакция катализатор промывался еще некоторым количеством растворителя (хлороформа) для извлечения адсорбированных на поверхности катализатора продуктов реакции. После прибавления небольшого количества безводного ацетата натрия выларивались изопрен, растворитель и большинство уксусной кислоты. Остаток обрабатывался водой и поташом. Далее определялся его вес и содержание ацетнльных групп.

Дальнейшую обработку продуктов реакции вели по следующей методике: сырой продукт реакции разделяли на фракции ацетатов путем перегонки в вакууме из колбы с елочным дефлегматором в атмосфере инертного газа. Были выделены следующие фракции:

1) фракция ацетатов $\mathrm{C}_{5}$ с $T_{\text {киा }} 45 \div 60^{\circ}$ (11 мм);

2) фракция ацетатов $\mathrm{C}_{10}$ с $T_{\text {киI }} 40 \div 110^{\circ}(5-3$ мм);

3) фракция ацетатов $\mathrm{C}_{15}$ с $T_{\text {киI }} 110 \div 150^{\circ}$ (2 мм);

4) остаток - высшие ацетаты.

Данные о фракционном составе в зависимости от условий проведения реакции и природы катализаторов приведены в табл. 2 теоретической части. Поскольку подробное исследование фракции $\mathrm{C}_{15}$ не входнло в рамки данной работы, в таблице дано суммарное количество остатка и фракции $\mathrm{C}_{15}$. Кроме того, все фракции частично перекрываются из-за широких пределов кипения углеводородной части продукта реакции.

3. Анализ продуктов реакции. Первнчный продукт реакции (ацетаты спиртов) анализировался на содержание ацетильных групп стандартным методом определения эфирного числа [14], однако из-за содержания $a$-терпиннл:ацетата в продуктах время тидролиза пришлось увеличить до двух часов. Эфирное число было определено также для отдельных фракций разгонки.

Для фракций спиртов $\mathrm{C}_{10}$, полученных методом экстракции из гидролнзата, было определено содержание гидроксила по методу Терентьева (см. [15]).

Кроме химических методов для анализа полученных фракций был использован метод газовой хроматографин. Для этого применялся газовый хроматограф Хром-1 (фирмы «Лабораторне Пристрое», ЧССР) с колонкой диаметрсм 2,5 м.м и длиной $11 \mathrm{M}$, наполненной $0,5 \%$ полиэтиленгликоля 4000 на хромосорбе W (30-60 меш). Газомносителем служила углекислота; скорость потока 15 мл/мин, давление на входе 2,4 атм, рабочая температура колонки $140^{\circ}$, испарителя $150^{\circ}$. Величина пробы составляла около 0,5 мкл; для получения такого количества пробы применялось разделение потока газа после испарителя $(1: 5)$. В приведенных условиях время проявления природного гераниола, очищенного через комплекс с $\mathrm{CaCl}_{2}$, составляло 23 мин (без признаков разложения). Не наблюдалось также разложения геранилацетата.

Хроматограмма (рис. 2) характеризует сложный состав смеси, полученной при реакции изопрена с уксусной кислотой.

4. Изучение индивидуального состава фракшии $\mathrm{C}_{10}$. Из полученных фракций при помощи газовой хроматографии подробно изучалась только фракция $\mathrm{C}_{10}$. После снятия хроматограммы фракция ацетатов подвергалась гидролизу 10\%-ным КОН в 90\%-ном метаноле на водяной бане в течение 2 ч в присутствии двукратного избытка щелочи для омыления трудноомыляемого ацетата $\alpha$-терпинеола. После отгонки ${ }^{2} / 3$ мета- 
нсла и прибавления воды продукт извлекался петролейным эфиром, высушивался и перегонялся.

Для детерпенизации полученного гидролизата были применены методы фталирования, борирования и селективной экстракции.

Для получения кислых фталатов по мегодике Л. Петровой и О. Шварца (см. [ $\left.\left.{ }^{14}\right]\right)$ исследуемую фракцию нагревали с равным весовым количеством фталевого ангидрида и двойным количеством бензола на кипящей водяной бане в течение 2 . После охлаждения приливали $5 \%$-ный раствор соды и тщательно перемешивали. Отделенные слои экстрагировали соответственно водой и бензолом для уменьшения потерь и вымывания примесей. Потом нз водяного слоя выделяли кислый фталевый эфир при подкислении раствора разбавленной серной кислотой и спирты регенерировали омылением $10 \%$-ным КОН в $90 \%$-ном метаноле на водяной бане. После отгонки $2 / 3$ метэнола и прнбавления воды спирты экстрагировались петролейным эфн . ром, высушивались, петролейный эфир выпаривался и спирты перегонялись.

Для получения боратов была применена методика, описанная А. Шумейко [10] для очистки линалоола. В первую очередь изготовляли трибутилборат из бутилового спирта и борной кнслоты. Полученным трибутилборатом в небольшом избытке обрабатывали терпеновые спирты в течение 30 минут при температуре бани $120^{\circ}$. Непрореагировавшая часть смесн перегонялась вместе с из-

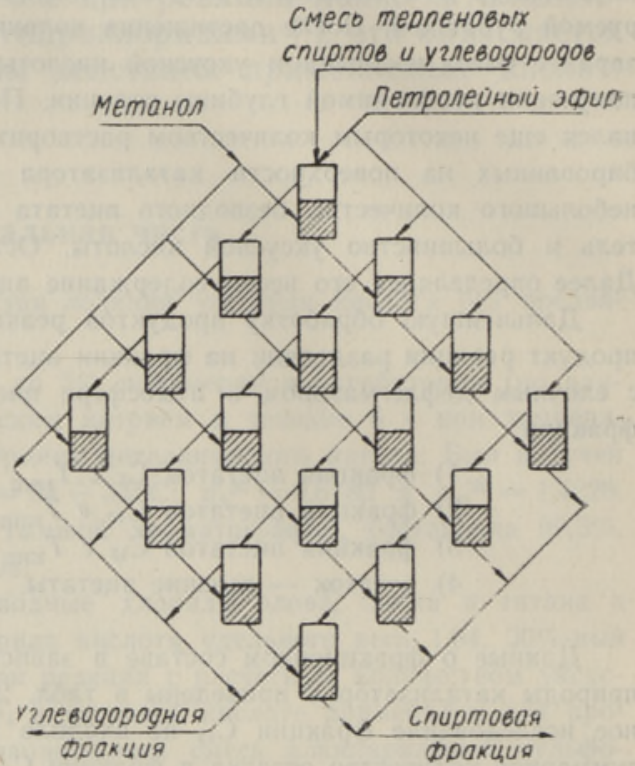

Рис. 1. Схема селективной экстракции смеси спиртов и углеводородов.

бытком трибутилбората в вакууме. Остаток разложили перегонкой с водяным паром в присутствин раствора соды; из водяного слоя отделили слой спиртов и растворенные в воде спирты извлекались петролейным эфиром, продукт высушивался и перегонялся.

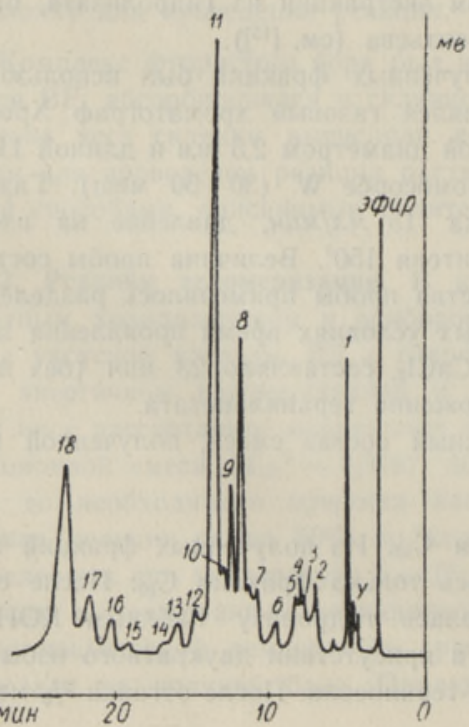

Для очистки гндролизата фракции $\mathrm{C}_{10}$ при помощи селективной экстракци и продукт обрабатывялся петролейным эфиром и метанолом по схеме, прнведенной на рис. 1; растворители предварительно смешивались в большой делительной воронке, после чего прибавлялась вода до расслаивания растворителей. Гидролизат растворялся в десятикратном количестве петролейного эфира. В зависимости от содержания углевсдородов в разделяемой фракщии применялись разные соотношения

Рис. 2. Хроматограмма спиртов $\mathrm{C}_{10}$, выделенных методом селективной экстракции.

Условия хроматографирования: прибор Хром-I, колонка длиноt $11 \mathrm{M}$, диаметром $2,5 \mathrm{M}$, давление газа-носителя $\left(\mathrm{CO}_{2}\right)$ на входе 2,4 атм, на выходе - атмосферное, температура анализа $140^{\circ}$, температура испарителя $150 \pm 10^{\circ}$, скорость газа-носителя 15 мл,мин, величина пробы 0,5 мкл (дознровка пробы и выпуск газа в соотношении $5: 1)$. Обозначення пнков см. в табл. 3 . 
Рис. 3. Хроматограмма фракции углеводородов, выделенных методом селективной экстракции. Условия хроматографирования см. рис. 2. $I$ - углеводороды $\mathrm{C}_{10}, 2$ - углеводороды $\mathrm{C}_{15}$ с примесями спиртов

растворителей. Обычно применялось соотношение $1: 2$ (петролейный эфир: метанол). По данным хроматографического анализа, метанольный экстракт не содержит углеводородов (рис. 2), некоторое количество спиртов остается в слое петролейного эфира (рис. 3 ).

Данные, полученные при газохроматографическом анализе спиртов фракций $\mathrm{C}_{10}$ теломера, приведены в табл. 3 теоретической части сообщения,

5. Выделение индивидуальных спиртов из фракции $\mathbf{C}_{10}$. Разделение терпеновых спиртов методом препаративной газовой хроматографии, описанной ранее [?], проводилось на колонке длиной 1 м, диаметром 20 мм, заполненной насадкой

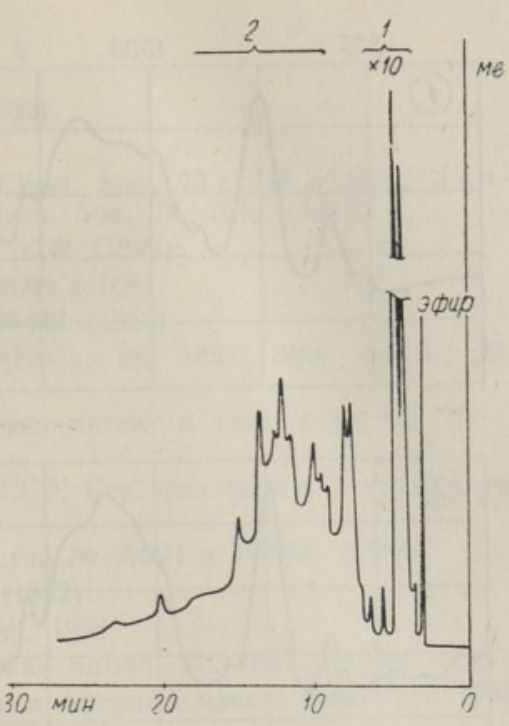
ИН3-600 (размером зерен 0,16-0,31 мм), с нанесенной в количестве $25 \%$ от веса носителя жидкой фазой полиокса 40. Метчдика обработки носителя и нанесения жидкой фазы также описана ранее [8]. Хроматографирование проводилось при температуре колонки $170^{\circ}$, испарителя $200^{\circ}$ и скорости потока газа-носителя (паров хлористого метилена) 1 мл конденсата в минуту, что соответствует линейной скорости газа около 3 см/сек; количество пробы составляло 0,6 мл. Разделению подвергалась смесь терпеновых спиртов фракции $\mathrm{C}_{10}$, полученной в опыте 16 , для выделения главных компонентов - спиртов с относительными временами удерживания (см. аналитическую хроматограмму рис. 2) 0,43 (пик 8), 0,47 (пик 9), 0,51 (пик 11) и 1,00 (пик 18). За 20 циклов разделения было пропущено 12,2 г смеси и получено четыре фракции в растворе хлористого метилена, которые были проанализированы на аналитическом хроматографе при вышеогисанных условиях. Выяснилось, что необходимо повторное разделение фракций, поэтому выпаривался хлористый метилен и пробы хроматографировались вторично. Из полученных фракций выпаривалсл хлористый метилен и фракции перегонялись в вакууме. Были получены продукты, характеристика которых приведена в табл. 1. Затем для этих продуктов были сняты инфракрасные спектры, которые подтверждают структуру синтезированных $\boldsymbol{\alpha}$-терпинеола и гераниола (рис. 4).

\section{Выводы}

1. Изучена реакция ионно-каталитической теломеризации изопрена с уксусной кислотой с использованием для определения состава продуктов реакции газовой хроматографии.

2. Установлено, что при данной реакции образуется сложная смесь геми-, моно-, сескви- и политерпеновых ацетатов и углеводородов. Более подробно изучена фракция монотерпеновых производных.

3. Разработана методика разделения гидролизата фракции $\mathrm{C}_{10}$ на спирты и углеводороды при помощи селективной экстракции и количественного газохроматографического определения состава оксипроизводных фракций $\mathrm{C}_{10}$.

4. Выделено при помощи препаративной газовой хроматографии четыре монотерпеновых спирта, из которых идентифицированы при помощи инфракрасных спектров только два: гераниол и $\alpha$-терпинеол. 

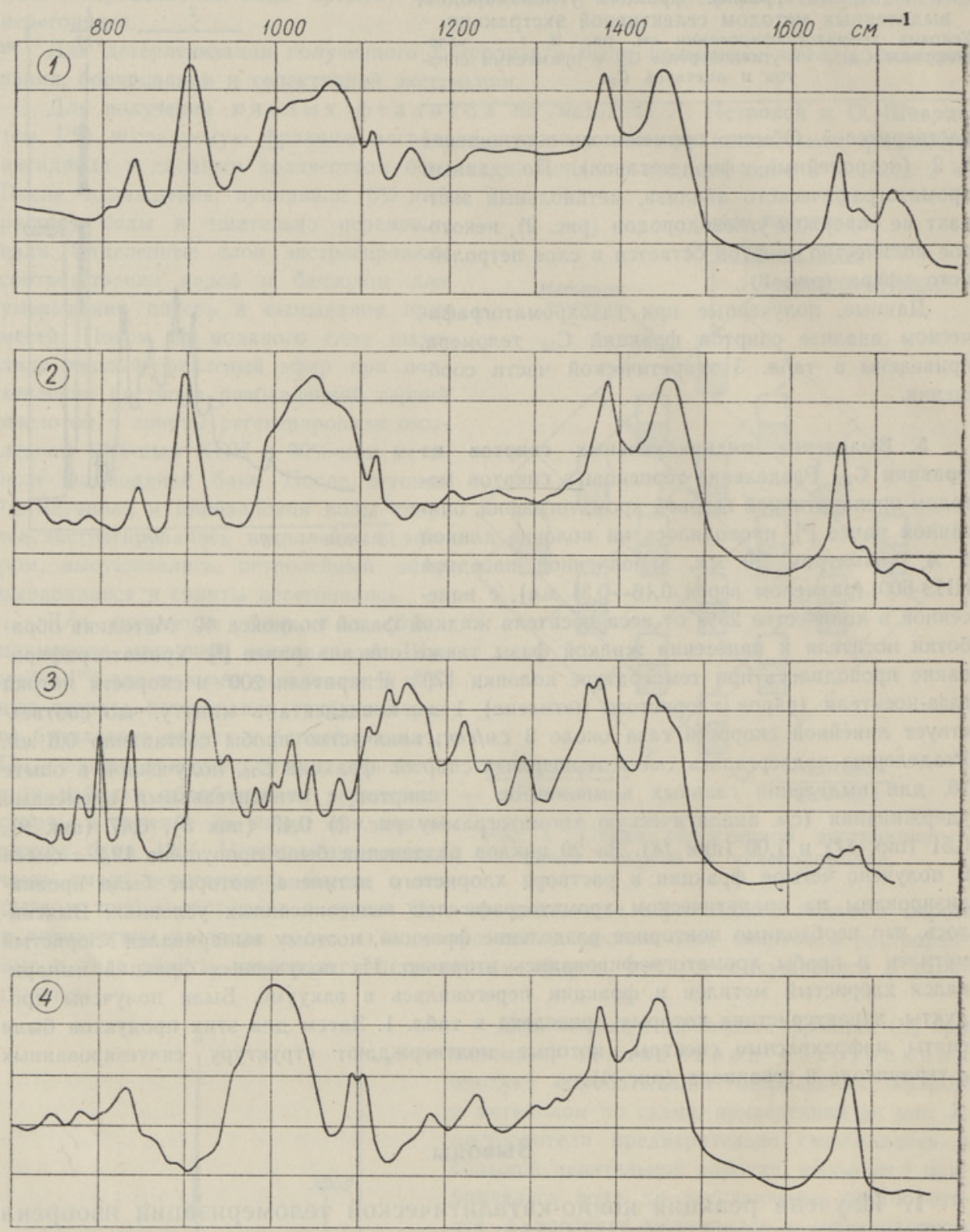

Рнс. 4. Инфракрасные спектры выделенных препаративно фракций спиртов:

1 - спирта $\mathrm{C}_{10}$ (пик 8), 2 - спирта $\mathrm{C}_{10}$ (пик 9), 3 - $\alpha$-терпинеола (пик 11 ), 4 - гераннола (пик 18), на приборе УР-10, прнзма $\mathrm{KBr}$, слой 0,28 мм.

5. Изучено влияние природы катализаторов и различных условий реакции на выход отдельных терпеновых ацетатов и установлены общие закономерности протекания такой реакции.

6. Установлено, что наилучшие выходы гераниола (до 6\% от использованного изопрена) наблюдаются при использовании в качестве катализатора реакции смеси алкиларильных сульфокислот. 
ЛИТЕРАТУ РА

1. Wagner-Jauregg Th., Ann., 496, 52 (1932).

2. Lennartz Th., Ber,, 76 B, 831 (1943).

3. Jenner Ed. J., S chreiber R. S., J. Am. Chem. Soc., 73, 4348 (1951); Jen ner Ed. J., C of f a men D. O., J. Am. Chem. Soc., 76, 2685 (1954).

4. Американский патент № 2460291 - С. А., 43, 3039 (1949).

5. Французский патент № 1349298 - С. А., 60, 12065 (1964).

6. Лээт с К. В., Авторское свидетельство № 105428 (1955).

7. Лээ т с К. В. и др., ЖОХ, 27, 1509, 2969 (1957); 28, 1823, 3096 (1958); 31, 1861 (1961).

8. Лээтс К., Эрм А., Изв. АН ЭССР. Сер. физ.-матем. и техн. наук, 13, № 1, $57(1964)$,

9. Л э э т с К., Э р м А., К р а а в Л., Изв. АН ЭССР. Сер. физ.-матем. и техн. наук, 15, № 2, 223 (1966).

10. Ш у мей ко А. К. и др., Авторское свидетельство № 99224 и 100393 (1954).

11. С алд да дз е К. и др., Пластмассы, № 3, 51, (1962).

12. Т о п ч и е в А. В. и др., Сб. Фтористый бор, М., 1956.

13. В ульфсон Н. С., Препаративная органическая химия, М., 1959, с. 115.

14. Горя я в М., Пли в а И., Методы исследования эфирных масел, Алма-Ата, 1962, c. 310,627 .

15. Г а т терман Л., Вил анд Г., Практические работы по орпанической химин, М.-Л., 1948, с. 96.

\section{Ннститут химии \\ Академии наук Эстонской ССР \\ Поступила в редакщию 15/VI 1966}

\section{A. ERM, K. LÄATS}

\section{ISOPREENI TELOMERISATSIOONIREAKTSIOONI UURIMINE ÄÃDIKHAPPE MANULUSEL}

Artiklis käsitletakse terpeenalkoholide sünteesi võimalusi isopreenist telomerisatsioonireaktsiooni abil. Selleks on erinevates tingimustes uuritud gaasikromatograafiliselt isopreeni reaktsiooni äädikhappega mitmesuguste katalüsaatorite juuresolekul. Tekkinud keeruka segu lahutamisel alkoholideks ja süsivesinikeks osutus parimaks meetodiks selektiivne ekstraktsioon. Preparatiivse gaasikromatograafia-aparatuuri abil eraldati neli alkoholi, milledest identifitseeriti $\boldsymbol{\alpha}$-terpineool ja geraniool nende inírapunaste spektrite järgi. Parimaks katalüsaatoriks terpeenalkoholide sünteesil osutus. alküülarüülsulfohapete segu, mis andis $6 \%$ geranioolisaagist.

\section{A. ERM, K. LÄATS}

\section{A STUDY OF THE TELOMERISATION REACTION OF ISOPRENE WITH ACETIC ACID}

This paper deals with the problem of the synthesis of monoterpenic compounds, especially alcohols on the basis of isoprene. The reaction of isoprene with acetic acid in the presence of various catalysts and reaction relationships has been studied by means of a gas chromatographic equipment. It was stated that the selectiveextraction is the best method for removing terpenes from alcohols. By means of the new preparative gas chromatographic apparatus four monoterpenic alcohols were separated, from which $\alpha$-terpineol and geraniol were differentiated by their infrared spectra. The best catalyst for the synthesis is mixture of alkylarylated sulphuric acids, giving the yield of geraniol about 6 per cent from reacted isoprene. 